\title{
Upaya Peningkatan Pengetahuan Anak Sekolah Minggu Tentang Virus Corona Di Masa Pandemi COVID-19
}

\author{
Remita Ully Hutagalung ${ }^{1}$, Theresia Tutik ${ }^{1}$, Kristina ${ }^{1}$ \\ ${ }^{1}$ Program Studi Diploma III Keperawatan \\ Sekolah Tinggi Ilmu Kesehatan Dirgahayu Samarinda J1. Pasundan 21 \\ Samarinda, Kalimantan Timur \\ *e-mail:remitaners@gmail.com
}

Informasi Artikel

Diterima Redaksi : 15 Desember 2020

Revisi Akhir : 03 Januari 2021

Diterbitkan Online : 28 Januari 2021

Kata Kunci:

Covid-19, Pandemi, Anak

\section{PENDAHULUAN}

Penyebaran virus corona yang semakin luas di Indonesia ternyata juga berdampak kepada anak anak usia sekolah. Gereja merupakan salah satu tempat pendidikan bagi anak anak usia sekolah. Anak sekolah khususnya dalam lingkungan pendidikan agama perlu dikenalkan tentang virus Covid19. Pengenalan tentang Covid-19 kepada anak akan meningkatkan pemahaman dan kewaspadaan anak. Oleh karena itu perlu adanya penyampaian materi pendidikan kesehatan mengenai bahaya Covid-19. Saat ini materi pendidikan kesehatan yang sesuai bagi anak anak, khususnya anak anak di lingkungan pendidikan keagamaan masih sangat minim. Melihat situasi tersebut, maka kami melakukan kegiatan pendidikan kesehatan tentang Covid-19 yang dikhusukan bagi anak anak sekolah minggu yang juga berisi materi tentang kerohanian. Adapun materi ini akan diberikan secara

\begin{abstract}
Abstrak
Pelaksanaan kegiatan pendidikan kesehatan bagi anak sekolah minggu di Gereja GPSI Alfa Omega Samarinda merupakan salah satu bentuk kegiatan pengabdian masyarakat yang dilaksanakan oleh dosen STIKES Dirgahayu Samarinda Program Studi Diploma III Keperawatan. Melalui pendidikan kesehatan anak sekolah minggu dapat mengenal tentang COVID-19 dan cara pencegahannya. Kegiatan ini dianggap penting karena belum tersedia materi pendidikan kesehatan tentang Covid-19 bagi anak anak di lingkungan gereja.Metode yang dipakai adalah pemberian materi edukasi tentang Covid-19 melalui kanal youtube milik Gereja GPSI Alfa Omega Samarinda. Hal ini dilakukan dalam rangka meminimalkan adanya kontak fisik sekaligus aplikasi revolusi industry 4.0. Hasil dari pendidikan kesehatan ini adalah peningkatan pengetahuan pada anak sekolah minggu di masa pandemic tentang Covid-19.
\end{abstract}

daring melalui kanal youtube sehingga meminimalkan resiko tertular dan mengaplikasikan revolusi industry 4.0 ditengah situasi pandemic.

\section{METODE}

Kegiatan pengabdian kepada masyarakat dengan sasaran anak anak usia sekolah di lingkungan keagamaan disiarkan melalui kanal youtube GPSI Alfa Omega Samarinda pada hari Minggu tanggal 7 Juni 2020.

Metode pelaksanaan edukasi ini adalah mellaui ceramah disertai dengan gambar tentang virus corona. Materi terdiri dari ; Apa itu virus corona, bentuk virus corona, tanda dan gejala mengidap virus corona, cara pencegahan dan upaya yang bisa dilakukan anak agar tidak tertular dan mempertahankan diri.

Pada akhir materi, penonton anak diberikan tautan yang berisi pertanyaan evaluasi tentang materi yang diberikan. 


\section{HASIL DAN PEMBAHASAN}

Kegiatan pengabdian kepada masyarakat dengan judul : Upaya Peningkatan Pengetahuan anak Sekolah Minggu Tentang Virus Corona diadakan secara daring melalui kanal youtube milik gereja GPSI Alfa Omega Samarinda yang beralamat di Jl. Aminah Syukur ni 56 Samarinda. Materi ini di tayangkan pada tanggal 7 Juni 2020. Tautannya adalah

https://www.youtube.com/watch?v=Scc 0p8VUpNg\&feature=youtu.be.

Materi pendidkan kesehatan diberikan 1 kali kemudian dilanjutkan dengan evaluasi pengetahuan tenatng materi yang disampaikan. Materi pendidikan kesehatan berisi tentang : Apa itu corona, ukuran virus corona, tanda dan gejala terkena penyakit corona, penularan virus corona, bagaimana pencegahan corona dan bagaimana tehnik batuk yang benar.

Materi disampaikan menggunakan media gambar kemudian dibuat menjadi video yang menarik untuk anak anak. Gambar yang digunakan adalah gambar yang dibuat sendiri disesuaikan dengan materi. Gambar dan suara dijadikan video agar anak anak menjadi lebih jelas dan paham. Materi disampaikan dengan menarik agar anak anak dapat memahami materi edukasi| dengan baik.

Pada akhir materi diberikan evaluasi yang berisi pertanyaan pengetahuan anak tentang materi yang telah diberikan. Materi evaluasi juga dilakukan secara daring menggunakan aplikasi G-Form. Didapatkan data responden yang mengisi tautan evaluasi sebanyak 30 orang.

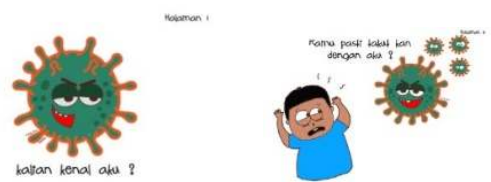

Gambar 1. Beberapa gambar yang digunakan untuk materi penyuluhan tentang Covid-19
Dari hasil pengumpulan data evaluasi didapatkan hasil sebagai berikut

1. Lokasi saat anak menyaksikan penyuluhan

Tabel 1. Lokasi anak saat menyaksikan

\begin{tabular}{|l|c|c|}
\hline \multicolumn{1}{|c|}{ Lokasi } & Jumlah & $\mathbf{\%}$ \\
\hline Samarinda & 27 & 90 \\
\hline Luar Samarinda & 3 & 10 \\
\hline TOTAL & 30 & 100 \\
\hline
\end{tabular}

2. Usia anak yang menyaksikan materi penyuluhan

Tabel 2. Usia anak

\begin{tabular}{|l|c|c|}
\hline \multicolumn{1}{|c|}{ Usia } & Jumlah & $\%$ \\
\hline 13 tahun & 1 & 3 \\
\hline 12 tahun & 9 & 30 \\
\hline 11 tahun & 5 & 17 \\
\hline 9 tahun & 5 & 17 \\
\hline 8 tahun & 3 & 10 \\
\hline 7 tahun & 4 & 13 \\
\hline 6 tahun & 2 & 7 \\
\hline 5 tahun & 1 & 3 \\
\hline TOTAL & 30 & 100 \\
\hline
\end{tabular}

3. Nilai rata rata evaluasi pengetahuan tentang materi penyuluhan

Setelah diberikan materi tentang Covid-19, anak sekolah minggu diberikan evaluasi pengetahuan. Pengukuran pengetahuan diberikan nilai $0-100$. Nilai terendah 0 dan nilai tertinggi 100. Didapatkan hasil sebagai berikut : 
Tabel 2. Hasil Evaluasi

\begin{tabular}{|l|c|c|}
\hline \multicolumn{1}{|c|}{ Nilai } & Jumlah & \% \\
\hline 8 & 1 & 3 \\
\hline 9 & 2 & 7 \\
\hline 10 & 27 & 90 \\
\hline TOTAL & 30 & 100 \\
\hline
\end{tabular}

\section{SARAN}

Anak anak sebagai kelompok umur yang memiliki resiko untuk tertular Covid-19 perlu diberikan pemahaman utnuk meningkatkan pengetahuan dan kewaspadaan agar terhindar dari Covid19. Untuk itu anak mendapatkan edukasi dengan metode lain yang menarik minat anak.

\section{UCAPAN TERIMA KASIH}

Ucapan terima kasih kepada STIKES Dirgahayu yang telah memfasilitasi pelaksanan kegiatan pengabdian masyarakat sesuai dengan bidang keilmuan.

\section{REFERENSI}

[1] (OECD), O. for E. C. and D. (2020). Women at the core of the fight against COVID-19 crisis. 30. https://doi.org/10.1787/92c0ef68en

[2] Li, X., Xu, W., Dozier, M., He, Y., Kirolos, A., \& Theodoratou, E. (2020). The role of children in transmission of SARS-CoV-2: A rapid review. Journal of Global Health, 10(1), 1-10. https://doi.org/10.7189/JOGH.10.0 11101

[3] Maarefvand, M., Hosseinzadeh, S., Farmani, O., Farahani, A. S., \& Khubchandani, J. (2020).

Coronavirus outbreak and stress in iranians. International Journal of Environmental Research and Public Health, 17(12), 1-11. https://doi.org/10.3390/ijerph1712 $\underline{4441}$
[4] Ontario, P. H. (2019). Negative Impacts of Community-Based Public Health Measures During a Pandemic (e.g., COVID-19) on Children and Families Key Findings. 2019, 1-26.

[5] Alwisol, Psikologi Kepribadian. UMM Press, 2009. 